\title{
The Süleymaniye Mosque: a computational fractal analysis of visual complexity and layering in Sinan's masterwork
}

\author{
Özgür Ediz and MichaelJ. Ostwald
}

Completed in the sixteenth century, the Süleymaniye Mosque in Istanbul has long been regarded as one of the great works of Sinan, the Ottoman Empire's foremost architect. In recent years, as our understanding of Sinan's design strategies and sensitivities has improved, a number of influential scholars have argued that there is a singular formal layering pattern present in Sinan's elevations. With the advent of recent advances in computational analysis it is possible to quantify the degree of visual layering (the hierarchical relationship between form, ornamentation and materiality) present in Sinan's Süleymaniye Mosque and thereby provide evidence, either for or against, this proposition. Using an advanced version of the computational fractal analysis method, the paper investigates the four facades of the Süleymaniye Mosque, along with two facade details, to provide a mathematical description of the layering visible in this building. Through this process the paper provides, for the first time, quantifiable data supporting the theorised properties of this famous building. In doing so, the paper also offers a description of the most advanced demonstration of fractal analysis ever applied in architecture.

\section{Describing Sinan's architecture}

Sinan was born during the last decade of the sixteenth century in the village of Agirnas, in the Kayseri province, in what is today central Turkey. While still in his teens, he was recruited into the 'devshirme' system and enrolled in the Janissary Corps where, in the school for apprentices, he learned carpentry and worked on building sites. During the reign of Süleyman the Magnificent, Sinan served in various military roles, gradually acquiring acclaim for his engineering skills and achievements. It was during the Moldavian campaign that the then chief architect, Acem Alisi, died, and Sinan was appointed to the post by the Prime Minister, Lütfi Pasha. ${ }^{2}$ Despite the fact that he was already of a mature age when he became chief architect, Sinan was to continue in the post for almost fifty years being responsible for the design, construction and restoration of over 400 buildings. ${ }^{3}$ Among the most famous buildings credited to his authorship are three mosques; the Shehzade Mosque in Istanbul from his 'apprenticeship' period, the Süleymaniye Mosque in Istanbul from his 'qualification' period, and the Selimiye Mosque in Edirne from his 'master' period. ${ }^{4}$ Such was Sinan's success, even during his lifetime, that he worked for three successive sultans and personally led the opening ceremony for the Süleymaniye Mosque. When Sinan died in 1588 he was buried next to the Süleymaniye Mosque, not far from the Sultan's grave.

Despite his extensive body of work, much of the research that has been undertaken into Sinan's buildings remains largely concerned with refining the historical record and, as a result of this, his buildings tend to be extensively described using the rhetoric of poetry, phenomenology or art history, rather than being analysed using a more systematic approach. For example, Godfrey Goodwin wrote several important works on Ottoman Architecture and he has offered evocative descriptions of Sinan's mosques on multiple occasions. ${ }^{5}$ Similarly, Arthur Stratton provided one of the early English language biographies of Sinan along with similarly informative and figurative descriptions of his work. ${ }^{6}$ It is not surprising that Sinan's buildings have tended to encourage modes of critical discourse that draw out the personal, symbolic or phenomenal impact of the work. These buildings have a powerful presence and not only as places of worship or spiritual contemplation. Such is their scale and material richness that they have resisted more comprehensive analysis until only relatively recently. For example, it has only been in the last two decades that scholars have begun to settle on an interpretation of the design qualities that distinguish Sinan's architecture.

It was Doğan Kuban who proposed that one of the key characteristics of Sinan's architecture rests in the priority he afforded to form over ornamentation. ${ }^{7}$ Whereas many mosques of the era were richly decorated, Sinan's design strategy appears to start with the clear expression of the visual and formal properties of the structure, followed by the selective decoration of these surfaces and then finally the 
clear expression of their underlying material presence. Gülru Necipoğlu paraphrases Kuban's argument as being that in Sinan's mosques 'ornament is subordinated to functional form, ${ }^{8}$ and 'decoration [has] absolutely no influence on the architectural design'. ${ }^{9}$ Jale Erzen offers a related description of the way in which Sinan used hierarchical layers and 'varied types of elements ${ }^{10}$ in different mosque facades to achieve particular 'visual effects'. ${ }^{11}$ For Erzen, there is a strong pattern in Sinan's architectural expression wherein a series of articulated structural members (typically columns, arches, beams and buttresses) frame recessed planes, which are in turn perforated by windows. Once this form has been defined, ornamentation is used to control the way light falls on walls, through windows and across thresholds. ${ }^{12}$ Finally decoration is minimal, as if Sinan wished to let the material of the underlying stone construction provide the final visual layer. It is this collective interpretation of Sinan's architecture as layered and hierarchical - a system where form dominates ornament, and materiality is seen as critical to the visual properties of the finished work - that has provided one of the first accessible and systematic accounts of Sinan's design strategy.

\section{Computational testing}

This paper proposes to develop evidence for (or potentially against) this evolving view of Sinan's design strategy using computational means. Therefore its purpose is not to interpret Sinan's architecture, but rather to begin to test the relationship that many recent scholars have theorised as existing between form, ornament and materiality in his designs. The focus of the analysis is one of Sinan's major buildings - the Süleymaniye Mosque - and the method employed to investigate the visual properties of this design is fractal analysis. But first, why fractal analysis?

This research is concerned with quantifying the relative visual dominance (or importance) of various elements in the elevations of the Süleymaniye Mosque. There are actually very few computational or mathematical methods for the analysis of the visual properties of architecture. Fractal analysis is the standard mathematical approach to determining the characteristic visual complexity of an object, form or image. The 'box-counting version' of the fractal analysis method has been chosen for the purposes of this paper because it is the most widespread and accepted approach used in any discipline for the analysis of the visual complexity of images. More than 1,500 research papers have been published using this approach in the sciences, engineering, mathematics and medicine.${ }^{13}$ While architectural scholars have previously proposed various methods for the visual analysis of facades, ${ }^{14}$ only the fractal approach has been repeatedly used by architectural researchers for almost two decades. ${ }^{15}$ However, the most detailed or intensive application of fractal analysis previously in architecture has been restricted to relatively small quantities of data; typically between 50 and 300 data points. In order to analyse the Süleymaniye Mosque using this method, a far larger set of data is required and so-despite the focus of this paper being on the testing of an interpretation of Sinan's architecture - it also records the most detailed application of fractal analysis to any building; a process involving more than one million data points.

The paper commences with a background to the Süleymaniye Mosque, its history and design. Thereafter the fractal analysis method is described and a brief example provided along with a discussion of its limitations. The particular variation of the method used in the present analysis is then explained. A full discussion of this method, which is almost forty years old,${ }^{16}$ is beyond the scope of the present paper and even the background to its architectural application would exceed the scale of the present work. ${ }^{17}$ For this reason only an overview is provided along with references to some of the better known or more accessible works which outline its machinations. In the section that follows the method, the results of its application in the Süleymaniye Mosque are recorded. These results mathematically describe the degree of visual complexity in the three main hierarchical layers form, ornament and materiality - of the design's facades. This analysis is undertaken for each layer, and for each of the four facades and for two facade details leading to eighteen separate sets of results. The results are then discussed in the context of dominant theories about Sinan's design strategy.

It must be acknowledged at the outset of this paper that any analysis of a building that is as intricate and revered as the Süleymaniye Mosque may incite disagreement. The problem is that no single approach to analysing such a building will ever capture its actual, experienced or imagined complexity. How can a building of this type ever be measured or evaluated when so many of its properties remain elusive? Several past descriptions, cited previously, have focused on colour, texture and acoustics; these are all valid, if necessarily restricted approaches. The present paper proposes an analysis of elevations; images which are at best an artificial representation of a completed building. But these elevations do possess a certain authority, as do all orthographic projections in architecture. ${ }^{18}$ They may have a diminished capacity to describe the building as it is experienced, but they are ideal for documenting and measuring its limits. ${ }^{19}$

\section{Sinan and the Süleymaniye Mosque}

Sinan's training as an army engineer gave him a thorough grounding in the practical aspects of architecture and, combined with the experience he gained through his travels, he soon developed a reputation first as an elegant adapter of ideas, ${ }^{20}$ and later as an innovative designer of buttressed and domed structures. ${ }^{21}$ For example, Goodwin compares Sinan's and Alberti's approach to the dome noting that the contrasts between these architects' works are as striking as their similarities. ${ }^{22}$ For Goodwin, the monuments of the Italian Renaissance are merely the sum of their parts, whereas for Sinan, 


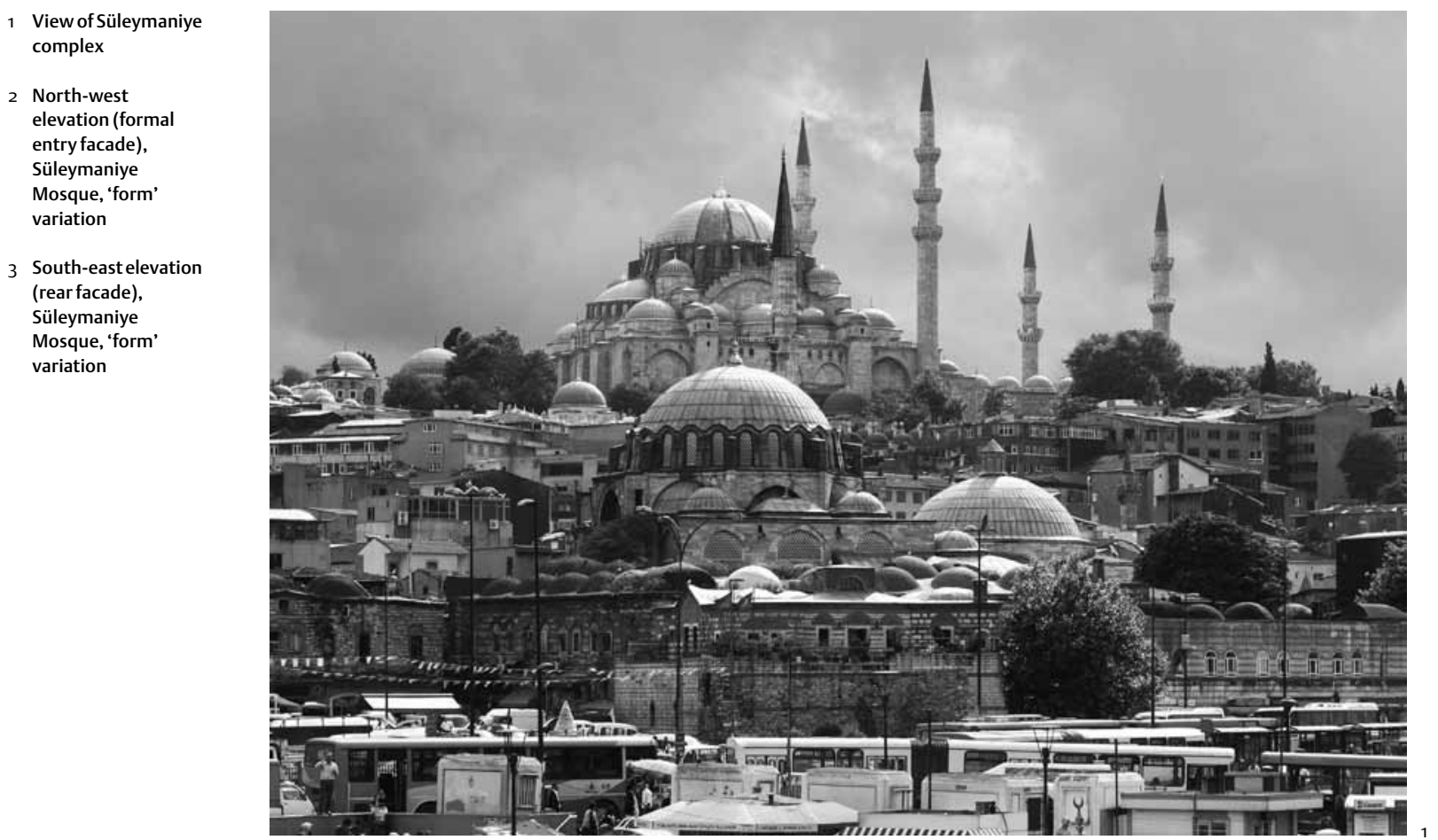

because the movement always leads upwards towards the central dome, the whole dominates the parts. Sinan also pioneered the use of smaller domes, semi-domes and buttresses, all of which lead one's eye up to the central dome while at the same time solving a practical structural problem of providing relatively column-free space for the mosque below. ${ }^{23}$ In combination, the visual and structural properties of the dome work together to create a clear, unified space of rational geometry and a place where the exterior and interior forms are in harmony. ${ }^{24}$ While this quality is present in many of Sinan's works, it is most often connected to his design of the Süleymaniye Mosque and külliye (complex of buildings adjacent to a mosque).

In the late 1540s, the Sultan Süleyman the Magnificent instructed his Chief Architect, Sinan, to build a mosque within a külliye which was to contain colleges, a hospital, a caravanserai and other buildings. It was in March 1548 that the Old Palace, on a gentle slope overlooking the Golden Horn, was chosen as the site for the new mosque complex. An inscription in Arabic on the foundation stonework - attesting to Süleyman's claim to the universal sultanate and caliphate - provides an official commencement date of 1550 and an inauguration date of 1557 , even though work began before that time and carried on afterwards. Indeed, parts of the complex were not completed until 1559, and the Sultan's own mausoleum was built by his son Selim II in $1566-68 .{ }^{25}$ The Süleymaniye complex was planned as a great centre of learning containing five madrasas for studies in theology and holy law and a sixth madrasa for a medical school. The complex is surrounded by a wide esplanade, along the outer sides of which are two rows of madrasas on the longer sides and social service buildings along the third side. The addition of further buildings at a later date, such as the hadith college, and the need to adapt
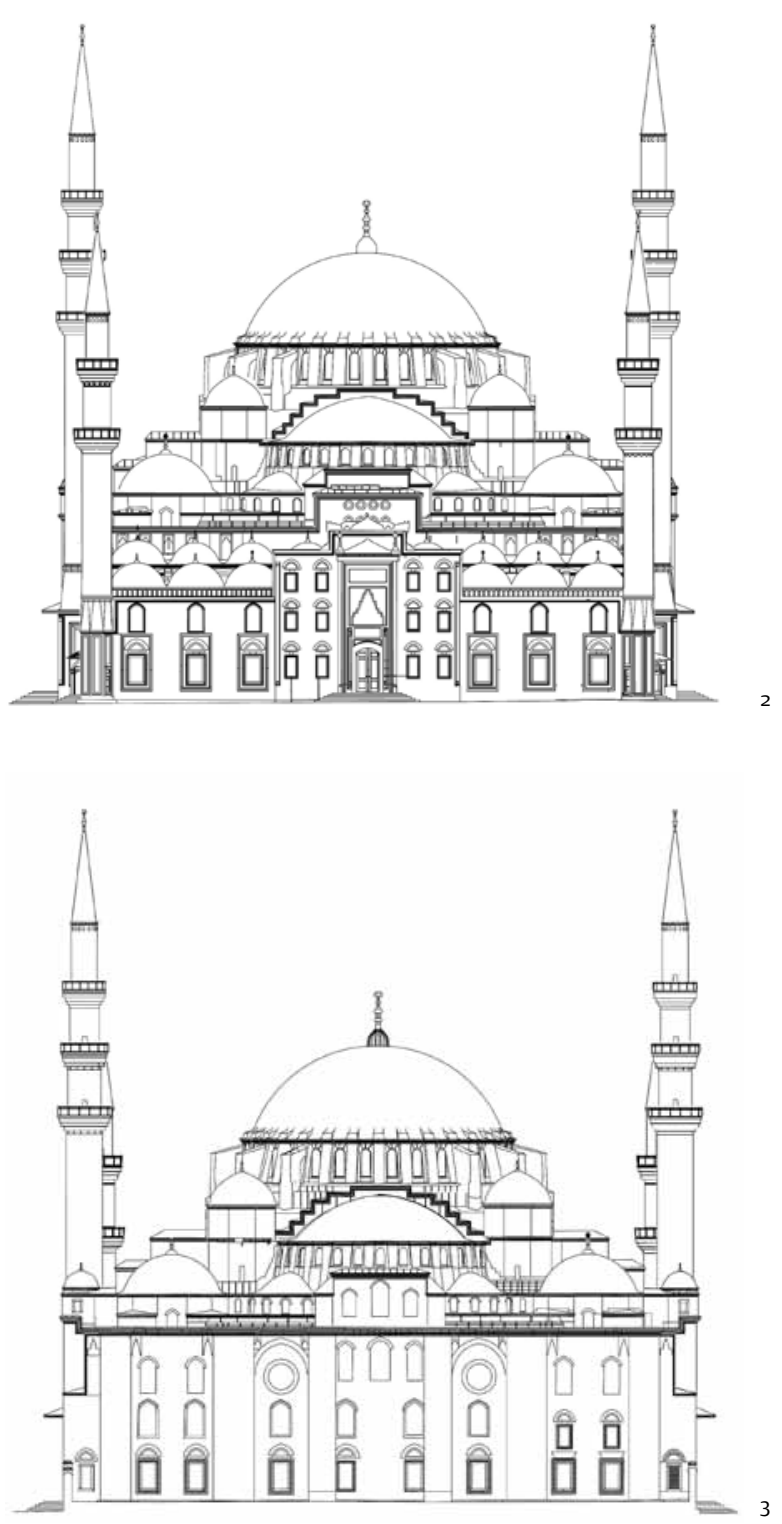

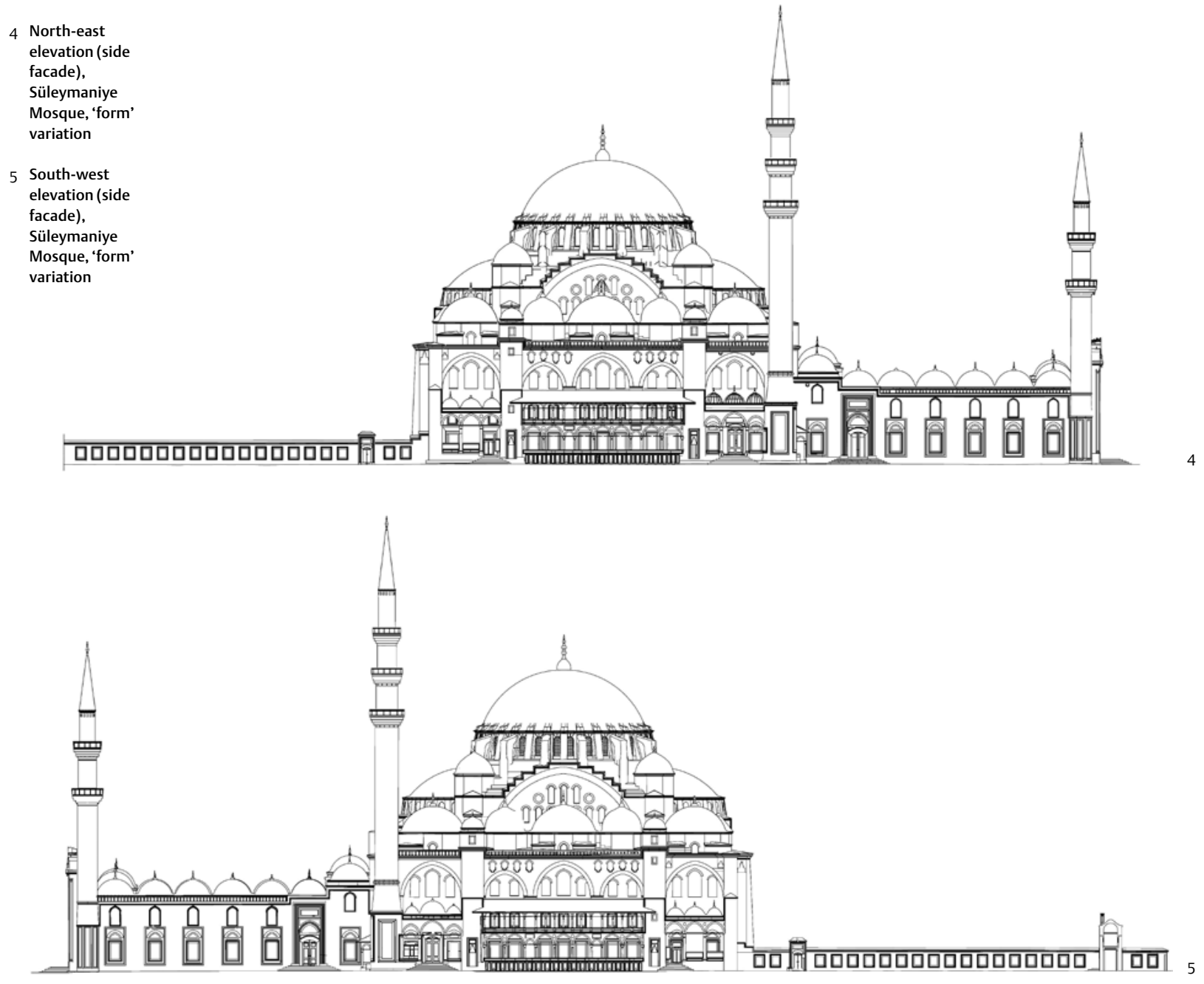

buildings to older street networks, explains the lack of strict symmetry. ${ }^{26}$ Around the mosque itself is a spacious courtyard, enclosed on three sides by stone walls, through the windows of which the sanctuary and funerary garden may be viewed. No wall was built on the fourth side, allowing for a panoramic view of the city and Golden Horn. Built in three dimensions on terraces, the Süleymaniye külliye appears to grow out of the hill on which it was built and to dominate the surrounding area [1].

At the centre of the Süleymaniye külliye is the mosque; an almost square form in plan, oriented to the qiblah (direction of Mecca, south-east) and surmounted by a single major dome. To the immediate north-west is the entry forecourt, its front facade divided by an ornate entry and marked at the corners with two minarets. Where the sidewalls of the forecourt meet the mosque there are two, taller minarets both framing the forecourt and signalling the entry to the interior space of worship. Just as the forecourt is engaged into the mosque to the north-west, to the south-east of the mosque's mihrab there is a long low, courtyard containing a number of mausoleums. In combination, this means that there are two short elevations to the mosque, the primary entry facade to the north-west [2], and the more private south-east facade overlooking Süleymaniye's tomb [3]. The long elevations to the north-east [4], and south west [5], are largely identical except for a few minor details around the transition zones between the primary dome and the secondary supporting ones. The mosque is separated from its exterior dependencies by a public avenue encircling the precinct wall. This not only sets the mosque and funerary garden apart as a sacred inner sanctum, but also ensures that the dependencies are able to interact with their urban surroundings. Within the mosque, decoration is kept to a minimum, in order to conform to the Sultan's demand for austerity and reverence. The inscriptions in the mosque emphasise religious orthodoxy and the attainment of paradise. It was in this mosque that floral Iznik tiles were used for the first time. Stained glass windows were also used in the qiblah wall; the mihrab is of marble.

\section{The fractal analysis method}

Fractals are geometric forms with non-integer dimensions. That is, we conventionally think of the world as comprising one-dimensional edges or lines, two-dimensional surfaces and three-dimensional volumes. However, Benoit Mandelbrot observed that in reality most lines have a degree of thickness and most surfaces have a degree of three-dimensional texture or depth. ${ }^{27}$ Thus, he proposed it is impossible to describe a real surface as having a dimension, or $D$, of 2 when it is demonstrably rough. Yet the surface may not yet be so complex as to constitute a three dimensional volume, or $D=3$, leading him to propose that perhaps the real dimension of the surface was somewhere between the two, say $D=\mathbf{2 . 4}$; 
a non-integer dimension. Furthermore, Mandelbrot discovered that many natural systems have similar levels of visual detail across multiple scales of observation; that is, the closer the system is observed, the more it resembles itself. ${ }^{28}$ Thus, from a distance a tree will often appear to be similar to a leaf from the same tree. This, the second quality of a fractal is called 'scaling', and it refers to the degree to which the visual complexity of the part resembles the visual complexity of the whole. ${ }^{29}$ However, to be technically correct, only ideal mathematical forms can have fractal geometry, while almost anything, regardless of its geometry, or lack of mathematical scaling, may have a fractal dimension. ${ }^{30}$ Thus, a building does not have to possess a repetitious pattern of nested rectangles to have a fractal dimension, but equally, no physical facade can be an example of true fractal geometry, which is mathematically defined and effectively endless in its capacity to scale.

There are various ways of determining the fractal dimension of objects, including buildings, and the most common, popularised by Mandelbrot in the late 1970 and early 1980 s, is the box-counting method. This approach, which has since become the standard in science, medicine and engineering, was, somewhat belatedly, adapted by Carl Bovill for architectural analysis in $1996 .{ }^{31}$ Bovill used a manual box-counting process to determine the approximate fractal dimension of several building facades. Since that time this approach to architectural analysis, with some low level processing support, has been repeated many times..$^{32}$ However, it is only in the last few years that a stable computational variation has been developed for architecture - a version which has since been widely published and used..$^{33}$

The box-counting method is used to approximate the fractal dimension of two-dimensional line images. Because this method analyses images of objects, the more refined the starting image, the more accurate the result. The method effectively determines the level of information present in an image, across multiple scales (analogously, from very close to more distant) and then calculates the typical spread of that information. Thus, it could be regarded as a measure of the consistency of the hierarchy of detail present in a facade. A facade may have multiple different scale features, from grand ceremonial doors, to pilasters and carved mouldings, but the method measures the average distribution of all of these features across all scales.

Importantly, the method does not differentiate between types of detail in an image; all lines being effectively equal as far as the process is concerned. Moreover, the computational method commences by using pattern recognition software to identify and convert all lines into single-pixel-width data, removing any potential for inconsistent processing. This facet of the method has two major implications. First, the drawings being analysed must typically be redrawn in a consistent way so that only the lines that represent the required architectural features are present. Without doing this, the results will be compromised by a range of graphic devices and practices which are not a fixed part of the building.
Second, in order to differentiate the complexity of specific architectural features (say the dominance of windows in a composition) multiple drawings of the facade (including, say, one with windows and one without) have to be prepared, processed and compared. The difference in the results between the two images then becomes more important than any individual result. Indeed, all comparative results using this method are more important than any single result in isolation. This is because the method is sensitive, but in a predictable way, to a wide range of practical considerations including image size, position and line width. However, if all of the images being analysed are produced and processed in the same way, then any minor 'errors' (typically less than $0.5 \%$ in magnitude) in the calculations will be consistent and thereby have no impact on the comparative result.

In practice, the box-counting method for architecture commences with an image; for example, a detail drawing of a standard courtyard window from the north-west facade of the Süleymaniye Mosque [6a]. A grid is then placed over that image and each square analysed to see if there are any of the lines of that elevation drawing present in the grid. The number of boxes with detail in it is then recorded [6b]. Then a grid of reduced size is overlain on the image and the same process is repeated, although now at a different scale, and the number of boxes with information in them recorded [6c]. This data is then processed using the following values;

$$
\begin{aligned}
& \mathrm{N}_{(\text {s\#) }}=\text { the number of boxes in grid number '\#' } \\
& \text { containing some detail. }
\end{aligned}
$$

$1 / \mathrm{s} \#=$ the number of boxes in grid number '\#' at the base of the grid. ${ }^{34}$

A comparison is then made of the number of boxes with detail in the first grid $\left(\mathrm{N}_{(\mathrm{s1})}\right)$ and the number of boxes with detail in the second grid $\left(\mathrm{N}_{(\mathrm{sz})}\right)$. Such a comparison is made by plotting a log-log diagram $\left(\log \left[N_{(s \#)}\right]\right.$ versus $\left.\log [1 / s \#]\right)$ for each grid size. The slope of the straight line produced by the comparisons - the approximate fractal dimension $(D)$ - is calculated as follows:

$$
D=\frac{\left[\log \left(N_{(s 2)}\right)-\log \left(N_{(s 1)}\right)\right]}{[\log (1 / s 2)-\log (1 / s 1)]}
$$

When this process is repeated a sufficient number of times, for multiple grid overlays on the same image, the average slope, or $D$ can be estimated. The key factors influencing the accuracy of this estimation are the number of grid comparisons used in the process and the size of the data set analysed (that is, the number of boxes counted in the complete set of calculations).

For the example of the mosque window detail [6a], the first overlay grid (a $6 \times 10$ configuration) has 34 cells with information (lines) contained in them [6b]. The overlay second grid, which is half the size of the first (or has a scaling coefficient of 2:1) has a $12 \times 20$ configuration and contains 88 cells with information in them [6c]. 

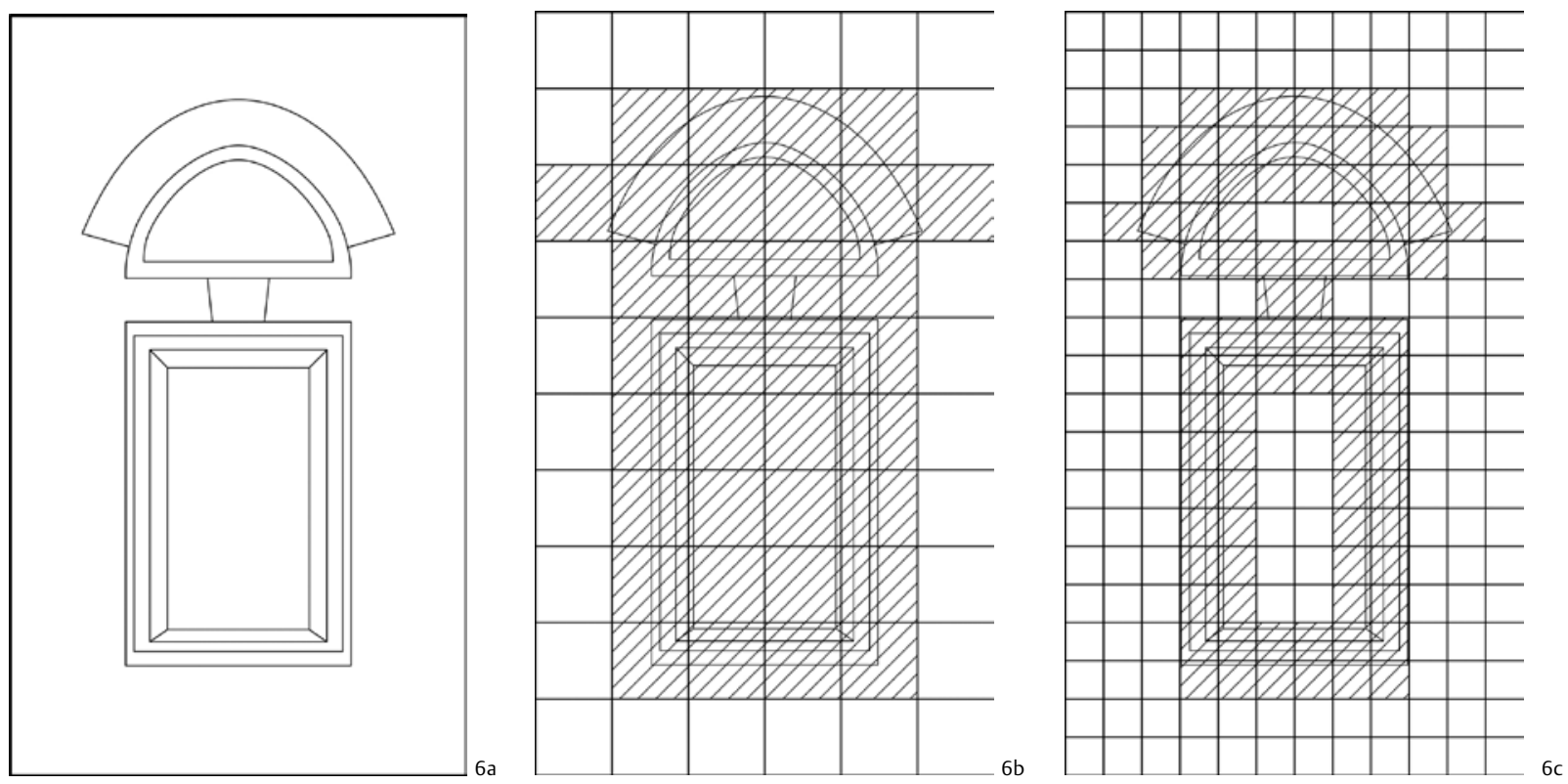

Using the previous formula, the comparison between the first and second grid is constructed mathematically as follows (note that in this calculation all figures are rounded to three decimal places):

$$
\begin{aligned}
D & =\frac{[\log (88)-\log (34)]}{[\log (12)-\log (6)]} \\
D & =\frac{[1.944-1.531]}{[1.079-0.778]} \\
D & =\frac{[1.944-1.531]}{[1.079-0.778]} \\
D & =\frac{0.413}{0.301} \\
D & =1.372
\end{aligned}
$$

Thus, the estimated fractal dimension of the window is 1.327. However, because this result is constructed from very little data (122 points over two scales), its accuracy is extremely limited (say, $\pm 25 \%$ ). If this comparison was repeated over 10 or more scales of grids, and using a larger starting image and commensurately more data points, an accurate (potentially $\pm 0.5 \%$ ) fractal dimension will be developed. It was the desire for increased accuracy that led to the need for a computational version of the method. The computational version used specially authored software to construct between eight and twelve comparisons of each image, producing many thousands of calculations that could not easily be replicated by hand. ${ }^{35}$

\section{Application of the method}

In past research the computational fractal analysis method has been used to consider what might be termed 'deliberate' or 'conscious' form. ${ }^{36}$ That is, those changes in volumetric or three-dimensional modelling that the architect has deemed worthy of visual expression. For the present analysis the authors have chosen to test the proposition that Sinan's buildings have a particular and consistent hierarchical visual quality. In order to undertake this research an artificial division - suggested by design

6 Box-counting example: window detail of the northwest facade of the Süleymaniye Mosque

scholars when reviewing Sinan's mosques - must be replicated in the method.

While acknowledging that the hierarchy of detail present in any historic facade is typically continuous over multiple scales - with the boundaries between forms, elements, patterns, materials and textures effectively blurred - past scholars have identified three layers in the facades of Sinan's architecture as worthy of distinction. ${ }^{37}$ These layers could be considered as comprising a hierarchy of the primary, secondary and tertiary visual detail in the facades.

1 Primary properties include the three-dimensional volume of the building as an expression of enclosure (walls and roofs), permeability (doors and windows) and structure. In the Süleymaniye Mosque these visual properties are largely associated with the formal expression of the structure (columns, beams, arches, vaults) and the programme (size of openings, covered walkways, enclosing walls).

2 Secondary elements are typically much smaller in scale and, in the Süleymaniye Mosque, include perforations or textures cut in stone screens, the decorative bars on windows, the carved calligraphy above doors and lunette windows and the stalactite forms in and around muqarnas vaults. While many of these visual elements do serve some practical purpose, the vast majority could be considered as types of ornament.

3 Tertiary properties include those that are defined by material joints or textures and some could be considered the result of exigencies in the construction process rather than being a conscious decision by the architect. Tertiary visual elements in the Süleymaniye Mosque include the visible joints between stones, the ridges in the dome roof cladding and the lead connections between steel bars. 
These three categories comprise the majority of the fixed properties of a building's visual expression. The more transitory qualities, associated with light, shade, reflection and weathering, are outside the scope of the analysis. Similarly, while the extent of the banks of decorative Iznik wall tiles with 'floral or inscriptive motifs ${ }^{3{ }^{8}}$ is noted on the drawings, the floral images themselves are not. Thus, for practical purposes, and to ensure a degree of methodological consistency, these three categories are subjected to analysis in the remainder of the paper. However, because architects do not talk about primary, secondary or tertiary visual properties, the three categories will be known hereafter as form, ornament and materiality. While acknowledging that the classification of some elements into these categories may be problematic, by using these descriptors it is possible to make connections to the work of past scholars who have offered extensive critique about the layering of form and ornament in the work of Sinan.

In order to commence the analytical process, a consistent set of measured drawings for the Süleymaniye Mosque was sourced and digitally retraced. These drawings record the mosque in its refurbished (1969) 'original' state, following damage by fire (166o), earthquake (1766), and a flawed nineteenth century reconstruction attempt. ${ }^{39}$ Two scales of analysis were required to test the characteristic visual complexity of the mosque and thus two facade details were chosen in addition to the four major elevations. Three versions of each of these six views were prepared by the authors, one version of each depicting just the facade form (primary), the second version including form and ornament (primary and secondary) and the final, form, ornament and materiality (primary, secondary and tertiary).

All images were uploaded into ArchImage software (Vers. 1.5) for processing and analysis. The software commences by scanning the image, using a Sobel edge detection algorithm, to identify all lines and convert them into one-pixel width thickness. This stage is necessary to prevent lines being counted twice (artificially increasingly the $D$ result) when the smallest boxes are being examined. Next, the software determines the optimal analytical grid location in accordance with the best practice use of the method in science. ${ }^{40}$ Finally, the software undertakes the box-counting process using a scaling coefficient (the relationship between each comparison grid and the next) or $\sqrt{2}: 1$ (approx 1.4:1) to calculate the fractal dimension of the image. ${ }^{41}$ This process is then repeated for the three variations of each of the six facade images.

Before progressing it is worth noting that for the two detail images, eleven iterations (grid comparisons) were required to produce each $\log / \log$ graph. The largest grid used was 142 pixels wide and the smallest just four pixels wide. In the most complex of the facade details, visual information was present in the smallest grid (the four by four pixel one) on 12,689 occasions. For the complete elevations, up to sixteen iterations of the process were required (for the two long elevations) with the largest grid being around 600 pixels wide and the smallest around four. At its highest count, the software analysed in one image 90,677 details in four by four pixel boxes and a total of 195,701 for the complete image. This is the highest number ever reported using the fractal analysis method in architecture.

\section{Discussion of results: facade details}

Before considering the large, complex elevations of the mosque, two elevation details were selected to demonstrate the analytical approach. The first detail to be examined is of the monumental 'north' portal of the forecourt; a facade panel which is located on the centreline of the north-west elevation. This three storey, symmetrical gatehouse structure has a central recessed door, surmounted by an elaborate muqarnas vault and 'a tympanum framed by half columns'. ${ }^{2}$ Above the entry door, with its tripartite foundation inscription, is a panel of carved Qur'anic calligraphy. On either side of the door, there are two windows for each of the three floors, all of which are positioned beneath separate carved arch and keystone forms.

If only the primary forms of the portal facade are analysed a $D_{(\mathrm{F})}$ result of 1.717 is produced [7a, Table 1]. If the carved ${ }_{\text {p }}^{(\mathrm{F})}$ anels, window mullions and bars and multiple layers of decorative roof finials are added to the facade, then a slightly higher result, $D_{(\mathrm{FO})}=\mathbf{1 . 7 5 4}$, is produced [ $7 \mathrm{~b}$, Table 1$]$. When the joints in the construction materials are included with the form and ornament the result is $D_{\text {(Fom) }}=1.865$ [7c, Table 1 ] In combination, this means that, relative to this facade in its totality, around $85 \%$ of the visual complexity is generated by the three-dimensional form, with its elaborate bevelled edges and expressed structure of columns, vaults, arches and pediments. The addition of recessed calligraphy, perforated screens and some subtle stone tracery at the cornice line only makes a $3.7 \%$ change to the visual complexity of the overall composition whereas the addition of lines produced by construction materials

\begin{tabular}{l|l|l|l|l}
\hline \multicolumn{2}{l|}{ Setting } & (a) Form & $\begin{array}{l}\text { (b) Form \& } \\
\text { Ornament }\end{array}$ & $\begin{array}{l}\text { (c) Form, } \\
\text { Ornament } \\
\text { \& Material }\end{array}$ \\
\hline Iteration & Box Size & Box Count & Box Count & Box Count \\
\hline 1 & 4 & 7737 & 8921 & 12689 \\
\hline 2 & 6 & 4011 & 4411 & 6212 \\
\hline 3 & 9 & 2085 & 2270 & 2853 \\
\hline 4 & 13 & 1119 & 1166 & 1412 \\
\hline 5 & 18 & 657 & 669 & 748 \\
\hline 6 & 25 & 380 & 388 & 405 \\
\hline 7 & 35 & 211 & 210 & 228 \\
\hline 8 & 50 & 111 & 112 & 109 \\
\hline 9 & 71 & 60 & 60 & 60 \\
\hline 10 & 100 & 34 & 34 & 34 \\
\hline 11 & 142 & 16 & 16 & 16 \\
\hline Fractal Dimension & $\mathrm{D}_{(\mathrm{F})}=1.717$ & $\mathrm{D}_{(\mathrm{FO})}=1.754$ & $\mathrm{D}_{(\mathrm{FOM})}=1.865$ \\
\hline$\%$ (Relative to whole) & 85.2 & 3.70 & 11.1 \\
\hline
\end{tabular}

Table 1 Results: fractal analysis of the entry facade, north-west elevation 

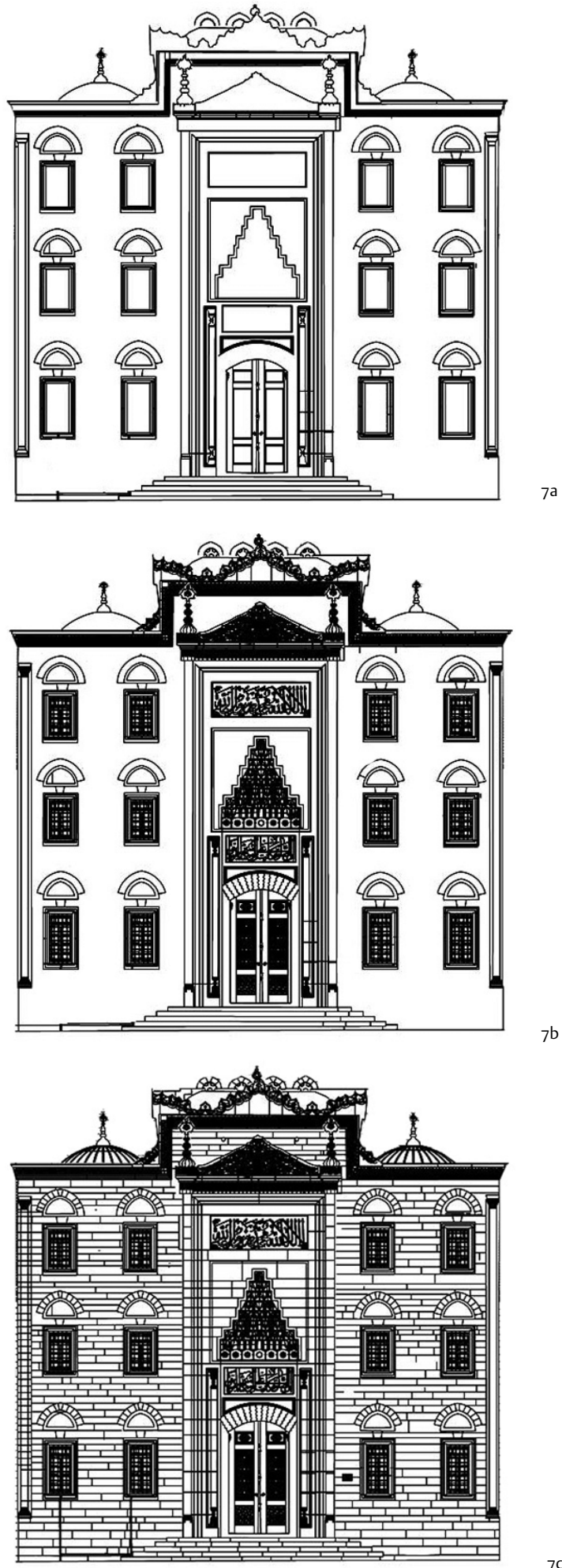

adds the final $11.1 \%$ to the overall visual complexity of the facade detail.

Another way of looking at this result is to imagine a person sited in a position, perpendicular to the line of the front facade, and far enough away from it that their normal gaze can take in the complete portal without movement of the head or eyes. From this position around $85 \%$ of the detail in the facade will be visible and if that person moves closer they will gradually have revealed to them the impact of the carved ornament on the facade, and finally, when they are even closer, they will read the texture of the materials that the facade is constructed from.

$\begin{array}{ll}7 \begin{array}{l}\text { Facade detail of the } \\ \text { entry facade, north- }\end{array} & \begin{array}{l}\text { Facade detail of a } \\ \text { typical courtyard }\end{array} \\ \text { west elevation } & \text { wall, north-east } \\ \text { a 'form' } & \text { elevation } \\ \text { b'form and } & a \text { 'form' } \\ \text { ornament' } & b \text { 'form and ornament' } \\ \text { c'form, ornament } & \text { c'form, ornament } \\ \text { and material' } & \text { and material' }\end{array}$

\begin{tabular}{l|l|l|l|l}
\hline \multicolumn{2}{l|}{ Setting } & (a) Form & $\begin{array}{l}\text { (b) Form \& } \\
\text { Ornament }\end{array}$ & $\begin{array}{l}\text { (c) Form, } \\
\text { Ornament } \\
\text { \& Material }\end{array}$ \\
\hline Iteration & Box Size & Box Count & Box Count & Box Count \\
\hline 1 & 5 & 2092 & 2236 & 4336 \\
\hline 2 & 7 & 1237 & 1241 & 2353 \\
\hline 3 & 9 & 795 & 790 & 1477 \\
\hline 4 & 13 & 409 & 416 & 732 \\
\hline 5 & 19 & 219 & 230 & 353 \\
\hline 6 & 27 & 141 & 129 & 192 \\
\hline 7 & 38 & 71 & 72 & 92 \\
\hline 8 & 53 & 50 & 49 & 62 \\
\hline 9 & 75 & 29 & 30 & 29 \\
\hline 10 & 106 & 16 & 16 & 16 \\
\hline Fractal Dimension & $\mathrm{D}_{(\mathrm{F})}=1.586$ & $\mathrm{D}_{(\mathrm{FO})}=1.596$ & $\mathrm{D}$ \\
\hline$\%$ (Relative & $=1.838$ \\
\hline
\end{tabular}

Table 2 Results: fractal analysis of a typical courtyard wall, north-east elevation

The second facade detail is taken from the exterior wall of the forecourt, of the north-eastern elevation, although it is typical of the forecourt detail on both facades. The forecourt wall is structured around a repeating motif of paired windows, the lower of each with a rectangular opening, but featuring a carved pointed arch above, which is, in turn, inside a proportionally larger rectangular panel. Directly above the first opening is a second window of the same width and proportion but this time the pointed arch form defines the extent of the opening. Above the cornice line, symmetrically sited along the centreline of the windows, is a dome and finial roof-form. This formal configuration is paired, and then repeated for the long perimeter walls of the forecourt.

When the form of this wall section is mathematically analysed a fractal dimension result of $D_{(\mathrm{F})}=\mathbf{1 . 5 8 6}$ is produced [8a, Table 2]. Once the perforated stone screen is added to the upper window, the lunette carved details to the half-circle panel and the steel and lead cross-work bars to the lower window, the fractal dimension result is raised marginally to $D_{(\mathrm{FO})}=1.596[8 \mathrm{~b}$, Table 2]. If then, the stone joints and material textures are included in the calculation, then the result rises relatively sharply to $D_{(\mathrm{FOM})}=1.838$ [8c, Table 2]. Before examining these three results together, it is worth considering a comparison with the results of the detail of the main entry portal. That previous detail featured much higher $D_{(\mathrm{F})}$ and $D_{(\mathrm{FO})}$ results, but the $D_{(\mathrm{FOM})}$ outcome is of a relatively similar level. This confirms that the entry portal is more highly moulded or formed $(1.717-1.586=0.131$ or $13.1 \%$ visual difference $)$ and that the ornament in the entry facade is more visually complex $(1.754-1.596=0.158$ or $15.8 \%$ 

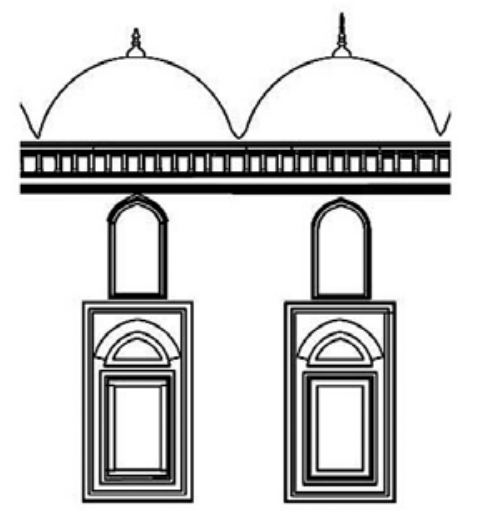
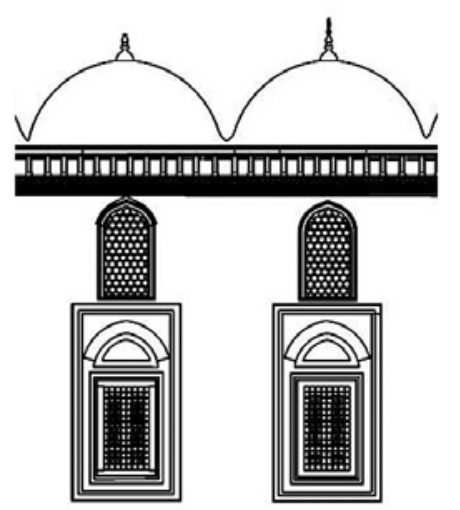

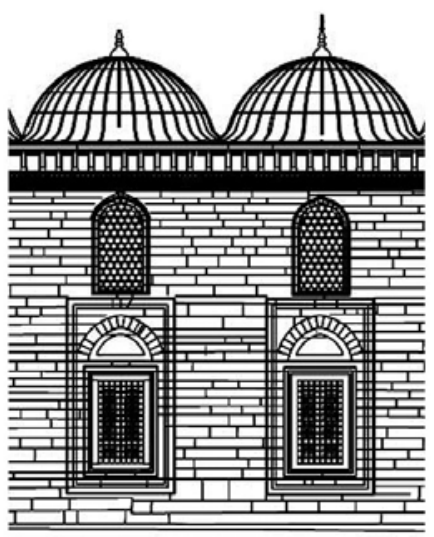

$8 c$ difference). However in terms of the overall impact of viewing the materiality of the facade from close range, the visual difference is diminished (1.865 $1.838=0.027$ or $2.7 \%$ difference). When viewed in isolation (relative only to itself), the visual complexity of the typical forecourt wall is $75 \%$ based on form, less than $1 \%$ on ornamentation and around $24 \%$ on material texture and joints [Table 2]. However, it must be remembered that this wall is much less visually complex than the entry portal facade detail.

\section{Discussion of results: main facades}

Before examining the quantitative results of this analysis, it is worth considering the traditional, qualitative interpretation of the visual characteristics of the Süleymaniye Mosque. Most historians and scholars propose that Sinan's architecture of this era is visually defined by a formal language of structural expression. Thus, engaged columns, arches, vaults and domes are the most common formal elements in his vocabulary. For example, Erzen argues that the 'organization and articulation of columns, pillars, buttresses and arches' not only supports the structure physically, but is also fundamental to its visual expression. ${ }^{43}$ Mainstone agrees noting that structural 'elements such as piers, arches, portals, and transitional vaulting elements [...] were singled out for emphasis' in the mosque facade. ${ }^{44}$ Kuban similarly proposes that 'Sinan's facades are articulated by structural necessity and textured by masterful fenestration'; ${ }^{45}$ his is an architecture that achieves its full visual complexity 'not by the shape of the individual elements, but by the totality of the building volume' ${ }^{46}$ If then, Sinan's architecture is visually dominated by structural expression, what is the place or role of ornament in the main elevations of the Süleymaniye Mosque?

Necipoğlu-Kafadar proposes that in the Süleymaniye Mosque 'they refrained from applying gilding (tezhib) and precious stones (tarsi)' to the facade and 'concentrated instead on [...] strengthening its structure. In other words, structural presence was regarded as more important than splendid decoration ${ }^{47}$ This view is echoed in the work of Mainstone who observes that decoration was 'confined to isolated panels on otherwise plain surfaces ${ }^{\prime 48}$ and when it did exist, '[g]eometric motifs were favoured, the stalactite being the most characteristic for capitals and transitional vaulting elements' ${ }^{49}$ This view is reinforced by Erzen who argues that more generally, 'decoration in Ottoman architecture was [...] used to accentuate [...] structural elements'.$^{50}$ The result of this practice is that the 'Ottoman dome is simple in its basic spherical shape; the minaret is slender and not ornamented except for its balconies, the kiosks have four arches and [for] a spherical dome, the arches are usually of simple round shape, or slightly ogival'.$^{1}$

These qualitative interpretations of the visual properties of the Süleymaniye Mosque suggest that the majority of the form will be derived from the expression of structure and that only a small proportion of the visual complexity of the building will be a direct result of ornament or decoration. There is little evidence that material expression was a major concern of Sinan, and many of the construction techniques appear to hide or suppress materiality in favour of structure. However, as time has passed, weathering has accentuated the joints in the materials and today this is a stronger part of the visual expression of the building. Few scholars have commented on the visual impact of the materiality in part because it is assumed to be subservient to the overall structure and form. For the purposes of the present research, all of the material joints are simply considered equal to all other detail (i.e., as lines), regardless of any change in visual prominence caused by weathering.

The mathematical analysis of characteristic visual complexity broadly supports the traditional interpretation of structure in the Süleymaniye Mosque as being the dominant element and with ornament playing only a minor role. The complete set of $D$ values, for each of the three variations and for all four elevations, is recorded [Table 3].

In addition, for each elevation a breakdown is provided of the weighting of the three variations, as a percentage relative to the rest of that elevation. Such weighted percentage values cannot be directly compared between elevations; any comparison must be made by determining the difference $\left(D_{\text {(diff) }}\right)$ between the original $\left(D_{(\mathrm{F}),} D_{(\mathrm{FO}),} D_{(\mathrm{FOM})}\right)$ results and then expressing this as a percentage.

The first facade to be analysed is the entry facade (the north-west) where the fractal dimension for the primary form is: $D_{(\mathrm{F})}=1.677$. The fractal dimension 


\begin{tabular}{|c|c|c|c|}
\hline Elevation & Variation & $\begin{array}{r}\text { Fractal } \\
\text { Dimension }\end{array}$ & $\begin{array}{r}\% \text { (Relative } \\
\text { to Whole) }\end{array}$ \\
\hline \multirow[t]{3}{*}{ North-west } & Form $\left[D_{(F)}\right]$ & 1.677 & 87.0 \\
\hline & Form + Ornament $\left[D_{(\mathrm{FO})}\right]$ & 1.689 & 1.20 \\
\hline & $\begin{array}{l}\text { Form + Ornament + } \\
\text { Materiality }\left[D_{(\mathrm{FOM})}\right]\end{array}$ & 1.807 & 11.8 \\
\hline \multirow[t]{3}{*}{ South-east } & Form $\left[D_{(F)}\right]$ & 1.598 & 80.8 \\
\hline & Form + Ornament $\left[D_{(\mathrm{FO})}\right]$ & 1.638 & 4.00 \\
\hline & $\begin{array}{l}\text { Form + Ornament + } \\
\text { Materiality }\left[D_{(\mathrm{FOM})}\right]\end{array}$ & 1.790 & 15.2 \\
\hline \multirow[t]{3}{*}{ North-east } & Form $\left[D_{(F)}\right]$ & 1.688 & 89.6 \\
\hline & Form + Ornament $\left[D_{(\mathrm{FO})}\right]$ & 1.702 & 1.40 \\
\hline & $\begin{array}{l}\text { Form + Ornament + } \\
\text { Materiality }\left[D_{(\mathrm{FOM})}\right]\end{array}$ & 1.792 & 9.00 \\
\hline \multirow[t]{3}{*}{ South-west } & Form $\left[D_{(F)}\right]$ & 1.674 & 87.3 \\
\hline & Form + Ornament $\left[D_{(\mathrm{FO})}\right]$ & 1.691 & 1.70 \\
\hline & $\begin{array}{l}\text { Form + Ornament + } \\
\text { Materiality }\left[D_{(\text {(FOM) }}\right]\end{array}$ & 1.801 & 11.0 \\
\hline
\end{tabular}

Table 3 Comparative results for north-west and south-east elevations

results for form and ornament and for form, ornament and materiality are, respectively, $D_{(\mathrm{FO})}=$ 1.689 and $D_{\text {(FоM) }}=1.807$. In comparison with the entry portico detail, which is a subset of this facade, the portico results were: $D_{(\mathrm{F})}=1.717, D_{(\mathrm{FO})}=1.754$ and $D_{\text {(FOM) }}$ $=1.865$. This means that in all three cases the portico detail is more visually complex than the average for the complete facade. This is the anticipated result because the entry is among the most detailed parts of the entire building exterior. The degree of variation can also be quantified by determining the difference between each result and expressing this as a percentage. Thus, in terms of the three variations of the first facade, the entry portico is more complex than the average visual complexity of the entire facade by, respectively, $D_{(\mathrm{FF})}+4 \%, D_{(\mathrm{FO})}+6.5 \%$ and $\mathrm{D}_{(\mathrm{FOM})}$ $+5.8 \%$.

The most private of the facades, the south-east, has fractal dimension results as follows: $D_{(\mathrm{F})}=1.598, D_{(\mathrm{FO})}=$ 1.638 and $D_{(\mathrm{FOM})}=1.790$. As anticipated, these are the lowest results for any of the three levels of visual detail, for any of the facades. Possibly the only unexpected outcome is that the degree of ornamentation, relative to the facade, is the highest of all four. Two factors are responsible for this result; the relative lack of primary form and the preponderance of windows (each of which have perforated or barred panels inset into them). Thus, in an otherwise understated facade, the ornamental screens in the windows produce a seemingly inflated, but accurate, result.

The north-east facade is the first of the long facades and, at first glance, it is almost identical to the southwest facades. In reality, the latter facade has an additional gate in the funerary courtyard wall, some more detailed dome connections and a subtle difference in door modulation. While these differences are tiny in comparison they might be expected to give the south-west facade a marginally higher $D_{(\mathrm{F})}$ or $D_{(\mathrm{FO})}$ result. The results for the northeast are: $D_{(\mathrm{F})}^{(\mathrm{F})}=1.688, D_{(\mathrm{FO})}=1.702$ and $D_{(\mathrm{FoM})}=1.792$. The results for the south-West are: $D_{(\mathrm{F})}=1.674, D_{(\mathrm{FO})}^{(\mathrm{FO})}=1.691$

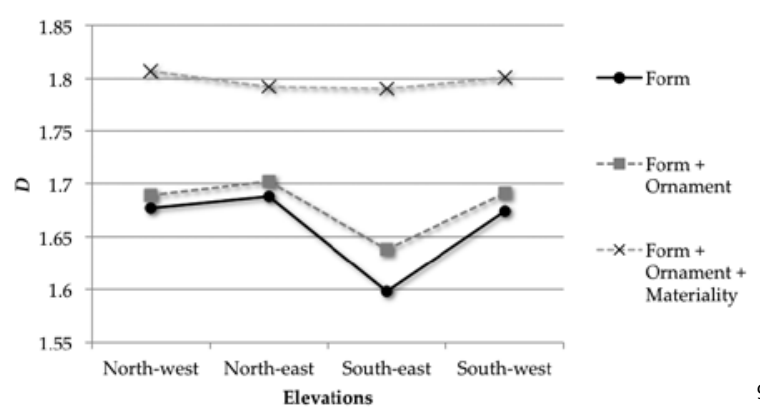

9 Graph of fractal

dimensions of three

levels of visual detail

for all four elevations

of the Süleymaniye

Mosque

and $D_{(\mathrm{FOM})}=1.801$. This means that, as anticipated, the south-west is marginally more complex although the difference at each level is very slight: $D_{(\mathrm{F} \% \text { diff. })}=+\mathbf{1 . 4} \%$, $D_{(\mathrm{FO} \% \text { diff.) }}=+1.1 \%$ and $D_{(\mathrm{FOM} \% \text { diff. })}=+0.9 \%$.

The second of the two details, for the forecourt exterior wall, is from the north-east elevation and a comparison between the two sets of $D$ results is informative. The $D_{(\mathrm{F})}=\mathbf{1 . 5 8 9}$ for the detail is $9.9 \%$ less than the $D_{(\mathrm{F})}=1.688$ for the elevation. Similarly, the result for the form and ornament present in a typical courtyard wall detail of $D_{(\mathrm{FO})}=\mathbf{1 . 5 9 6}$ is $\mathbf{1 0 . 6 \%}$ less than the result $\left(D_{(\mathrm{FO})}=1.702\right)$ for the complete elevation. Only the last variation, including material joints, reverses this trend with the detail showing $4 \%$ higher than the whole elevation for materiality. The first and second results are reasonably common sense; the form and ornament present in even a relatively ornate courtyard facade will be less than for a large mosque with multiple domes and minarets. The third is less intuitive, but it is readily explained by the observation that in the courtyard detail, the only materials are stones, with regular, small-scale joints, whereas in the total elevation, a high proportion of the materials are roof panels, with large-scale joints. Thus, the fine scale materiality of the facade has typically more visual complexity than the average for the whole elevation.

When the results for the four facades are charted, for each of the three variations, it becomes apparent that materiality contributes a surprisingly high, and unexpected, proportion of the visual complexity of the building [9]. While the relationship between structural form and ornamentation reflects the traditional scholarly interpretation of the building - wherein structure dominates - materiality (or texture) has a substantial, and previously ignored, impact on the layering of visual complexity of the building. The remainder of the results largely confirm, but quantify for the first time, expected outcomes. For example, the entry facade (north-west) and the two long facades (north-east and south-west) have similar levels of formal and ornamental complexity. The rear facade (south-east), to Süleymaniye's mausoleum, is the simplest, with the lowest form, ornament and materiality results for the entire building. 


\section{Conclusion}

Kuban, Necipoğlu and Erzen, among others, have suggested that an important feature of Sinan's architecture in general, and of the Süleymaniye Mosque in particular, is the relative lack of significance of decoration or ornamentation in the overall visual composition of the work. Instead, they argue that structural form is the primary visual determinant of the architectural qualities of the mosque. In order to test this proposition, this paper has quantified the relative importance of visual layering (or hierarchy of detail) present in the exterior facades of the mosque. The computational analysis has strongly supported the claims of these scholars although it has also identified a significant additional factor: the visual impact of materiality or texture.

The Süleymaniye Mosque has been the subject of repeated qualitative analysis for many years, increasing our understanding of the great work, but still defying attempts to come to a heightened understanding of its formal and visual qualities. While fractal analysis cannot provide a definitive interpretation of the building, it can assist in offering mathematical evidence for a range of common interpretations of the work and illuminate additional, previously ignored, dimensions of the building. Furthermore while the fractal analysis of a single building is of interest, a comparison between the Süleymaniye Mosque and Sinan's earlier or later works would be particularly informative in charting how his approach to form and structure evolved both over time, and in response to his experience of Hagia Sofia. Future research by the authors will consider these questions in the context of an analysis of masterworks from Sinan's other architectural periods: from his apprenticeship period, the Shehzade Mosque, and from his mastership period, the Selimiye Mosque.

\section{Notes}

1. Reha Günay, Sinan: The Architect and His Works (Istanbul: Yapi Endüstri Merkezi Yayinlari/Mimarlik Dizisi, 2009).

2. Rowland J. Mainstone, 'Sinan's Süleymaniye Mosque and Justinian's Hagia Sophia', in Structure in Architecture: History, Design and Innovation, ed. by Rowland J. Mainstone (Aldershot: Ashgate, 1999), pp. 351-59.

3. J. M. Rogers, Sinan (Oxford: Oxford University Press, 2006).

4. Aptullah Kuran, Mimar Sinan (Istanbul: Hürriyet Vakfi Yayinlari, 1986), pp. 22-23.

5. Godfrey Goodwin, A History of Ottoman Architecture (London: Thames and Hudson, 1971); Godfrey Goodwin, Sinan: Ottoman Architecture and its Values Today (London: Saqi Books, 1993).

6. A. Stratton, Sinan (New York: Charles Scribner's Sons, 1972).

7. Doğan Kuban, 'The Style of Sinan's Domed Structures', in Muqarnas, 4 (1987), 72-97; Doğan Kuban, Sinan's Art and Selimiye (Istanbul: Economic and Social History Foundation, 1997).

8. Gülru Necipoğlu, The Age of Sinan: Architectural Culture in the Ottoman Empire (London: Reaktion Books, 2005), p. 15.

9. Necipoğlu, Age of Sinan, p. 15.

10. Jale N. Erzen, Sinan Ottoman Architect: An Aesthetic Analysis (Ankara: Middle East Technical University, 2004), p. 145.

11. Ibid., p. 145.

12. John Freely and Augusto Romano Burelli, Sinan: Architect of Suleyman the Magnificent and the Ottoman Golden Age (London: Thames and Hudson, 1992).

13. Francesco Camastra, 'Data Dimensionality Estimation Methods: A Survey', Pattern
Recognition, 36 (2003) 2945-2954; K. Foroutan-Pour, P. Dutilleul and D. L. Smith, 'Advances in the Implementation of the Boxcounting Method of Fractal Dimension Estimation', Applied Mathematics and Computation, 105.2 (1999), 195-210; P. A. Asvestas, G. K. Matsopoulos and K. S. Nikita, 'Applications of Fractal Theory on Medical Data Processing', in Advanced Infrastructures for Future Healthcare, ed. by A. Marsh, L. Grandinetti, T. Kauranne (Amsterdam: IOS Press, 20oo), pp. 425-41.

14. Most methods for the computational analysis of architecture are focused almost exclusively on plans (Space Syntax) or on formal geometry (Shape Grammar). Some of the exceptions to this, which focus on the analysis of elevations, include: $\mathrm{M}$.

Krampen, Meaning in the Urban Environment (London: Pion, 1979); Arthur Stamps III, 'Architectural Detail: Van der Laan Septaves and Pixel Counts', Design Studies, 20 (1999), 83-97.

15. The first recorded application of the box-counting method being used in the urban analysis of architecture was published in 1993/4. Since that time around twenty-five major studies using this method have been published on the geometry of skylines, street patterns and public spaces. See: Michael Batty and Paul Longley, Fractal Cities: A Geometry of Form and Function (Academic Press: New York, 1994); G. Shen, 'A Fractal Dimension Analysis of Urban Transportation Networks', Geographical \& Environmental Modelling, 1 (1997), 221-36.

The first application of this method to architectural analysis (isolated from context) was published in 1996. Since that time around fifty papers have been published that have been focused on the fractal analysis of architectural elevations. See: Carl Bovill, Fractal Geometry in Architecture and Design (Basel: Birkhäuser, 1996); Michael J. Ostwald, Josephine Vaughan and Chris Tucker, 'Characteristic Visual Complexity: Fractal Dimensions in the Architecture of Frank Lloyd Wright and Le Corbusier', Nexus VII, Architecture and Mathematics, ed. by K. Williams (Turin: KW Books, 2008), pp. 217-32.

16. Richard Voss is often credited with formalising the first mathematical version of the box-counting method for fractal analysis, although Benoit Mandelbrot's work of the 1970s (translated into English in 1977) is among the most well-known early examples. See: Benoit Mandelbrot, Fractals: Form, Chance, and Dimension (San Francisco: W. H. Freeman, 1977).

17. The history of fractals and fractal analysis in architecture can be found in various places including: Michael J. Ostwald, 'Fractal Architecture: Late Twentieth Century Connections Between Architecture and Fractal Geometry', Nexus Network Journal, 3.1 (2001), 73-84; Michael J. Ostwald, 'Fractal Architecture: The Philosophical Implications of an Iterative Design Process', Communication and Cognition, 36.3-4 (2003), 263-95.

18. Robin Evans, The Projective Cast: Architecture and its Three Geometries (Cambridge, MA: MIT Press, 1995).

19. Robin Evans, Translations from Drawing to Building and Other Essays (Cambridge, MA: MIT Press, 1997). 2o. Alpay Ozdural, 'Sinan's Arsin: A 
Survey of Ottoman Architectural Metrology', Muqarnas, 15 (1998), 101-15.

21. Kuban, 'Sinan's Domed Structures'.

22. Goodwin, History of Ottoman Architecture.

23. Turgut Cansever, 'The Architecture of Mimar Sinan', AD: Architectural Design, 74.6 (2004), 64-70.

24. Kuban, 'Sinan's Domed Structures'.

25. Necipoğlu, Age of Sinan.

26. Günay, Sinan.

27. Mandelbrot, Fractals: Form, Chance and Dimension.

28. Benoit Mandelbrot, The Fractal Geometry of Nature (New York: W. H. Freeman and Company, 1982).

29. Michael Barnsley, Fractals Everywhere (Boston: Academic Press, 1988).

30. See: Benoit Mandelbrot 'Fractals and the Rebirth of Iteration Theory', in The Beauty of Fractals, ed. by H. O. Peitgen and P. H. Richter (New York: Springer-Verlag, 1986), pp. 151-6o.

31. Bovill, Fractal Geometry.

32. William Bechhoefer and Marilyn Appleby, 'Fractals, Music and Vernacular Architecture: An Experiment in Contextual Design', in Critical Methodologies in the Study of Traditional Environments (Berkeley: University of California at Berkeley, 1997); Wolfgang Lorenz, Fractals and Fractal Architecture (Vienna: Vienna University of Technology, 2003); Gerardo Burkle-Elizondo, Nicoletta Sala and Ricardo David ValdezCepeda, 'Geometric and Complex Analyses of Maya Architecture: Some Examples', Nexus V: Architecture and Mathematics (Turin: KW Books, 2004); Gaye Gözübüyük, Gülen Çagdas, and Özgür Ediz, 'Fractal Based Design Model for Different Architectural Languages', in The Architecture Co-Laboratory Game Set and Match II: On Computer Games, Advanced Geometries, and Digital Technologies, ed. by K Oosterhuis and L. Feireiss (Rotterdam: Episode Publishers, 2006), pp. 280-87.

33. See: Ostwald, Vaughan and Tucker, 'Characteristic Visual Complexity'; Michael J. Ostwald, Josephine Vaughan and Stephan K. Chalup,

'A Computational Investigation into the Fractal Dimensions of the Architecture of Kazuyo Sejima', Design Principles and Practices: An International Journal, 3.1 (2009), 231-44.; Michael J. Ostwald, and Josephine Vaughan, 'Visual Qualities in Early Modern and Late Modern Architecture: A Mathematical Comparison of Formal Complexity in the Houses of Gray and Sejima', in Computing, Cognition and Education: Recent Research in the Architectural Sciences, ed. by Ning Gu, Michael J. Ostwald and Anthony Williams (Sydney: ANZSACA, 2009), pp. 9-32.; Michael J. Ostwald and Josephine Vaughan 'The Mathematics of Style in the Architecture of Frank Lloyd Wright: A Computational, Fractal Analysis of Formal Complexity in Fifteen Domestic Designs', Built Environment: Design, Management and Applications, ed. by Paul S. Geller (New York: Nova Scientific, 2010), pp. 63-88.

34. See: Bovill, Fractal Geometry; Nicoletta Sala, 'Fractals in Architecture: Some Examples', in Fractals in Biology and Medicine Volume III, ed. by G. Losa, T. F. Nonnenmacher, D. Merlini, E. R. Weibel (Basel: Birkhäuser, 2002), pp. $347^{-58}$.

35. Ostwald, Vaughan and Tucker, 'Characteristic Visual Complexity'.

36. Bovill, Fractal Geometry; Ostwald, 'Philosophical Implications'.

37. Kuban, Sinan's Art; Erzen, Sinan Ottoman Architect; Necipoğlu, Age of Sinan.

38. Erzen, Sinan Ottoman Architect, p. 65 39. Gülru Necipoğlu-Kafadar, 'The Suleymaniye Complex in Istanbul: An Interpretation', Muqarnas, 3 (1985), 92-117 (p. 106).

40. Based on the work of: ForoutanPour, Dutilleul and Smith, 'BoxCounting Method'; Lorenz, Fractals 41. Scaling coefficients which are constantly divisible are the most useful for fractal analysis and Bovill used a 2:1 ratio, effectively halving the size of each box. However, this drastically reduces the number of comparative results thereby reducing the accuracy of the method, and thus a smaller, but still divisible, scaling coefficient is preferable. Because any solution which is not divisible by two creates a minute, but still different amount of white space around the starting image, then some mid-point must be achieved. The $\sqrt{2}$ solution balances the need for finer grain data collection with the need for easy scaling. See the discussion in: Bovill, Fractal Geometry; Sala, 'Fractals in Architecture'; Lorenz, Fractals; Ostwald, Vaughan and Tucker, 'Characteristic Visual Complexity'; Ostwald and Vaughan, 'The Mathematics of Style'.

42. Francis D. K. Ching, Mark M. Jazombek, Vikramaditya Prakash, A Global History of Architecture (New Jersey: John Wiley \& Sons, 2007), p. 530.

43. Erzen, Sinan Ottoman Architect, p. 65 44. Mainstone, 'Sinan's Süleymaniye Mosque', p. 355.

45. Kuban, 'Sinan's Domed Structures' p. 79

46. Ibid., p. 79
47. Necipoğlu-Kafadar, 'The Suleymaniye Complex', p. 107. 48. Mainstone, 'Sinan's Süleymaniye Mosque', p. 355

49. Ibid., p. 355.

5o. Erzen, Sinan Ottoman Architect, p. 65 51. Ibid., pp. 197-8.

\section{Illustration credits}

arq gratefully acknowledges:

Authors, 2-9, all tables

Istanbul Vakiflar Müdürlüğü (permission granted 2009 for use of original measured drawings, which have been adapted by the authors), 2-8

Wikimedia Commons, 1

\section{Acknowledgements}

An Australian Research Council (ARC) Fellowship (FTo991309) and an ARC Discovery Grant (DP1094154) supported the research undertaken in this paper. ArchImage, fractal analysis software, is by Steven Nicklin, Michael J. Ostwald, Stephan K. Chalup and Josephine Vaughan.

\section{Biographies}

Özgür Ediz is Associate Professor and Vice Chair of the Architecture Department at Uludag University, Bursa, Turkey. He has a Ph.D. in architectural design and theory titled 'A Fractal Based Approach in Early Design Phase'. His areas of interest are design computing, fractal based design, architectural design theories design studio and generative design. Özgür has won awards in many national architectural competitions, taken part in international competitions and produced numerous articles and papers.

Michael J. Ostwald is Professor and Dean of Architecture at The University of Newcastle (Australia) and an ARC Future Fellow. He has a Ph.D. in architectural history and theory and a higher doctorate (D.Sc.) in design mathematics and computing. Michael has been awarded more than fifty national and international research grants and has produced more than 300 scholarly publications including twenty-four books.

\section{Authors' addresses}

Dr Özgür Ediz

Uludag University

Department of Architecture

Bursa

Turkey

ozgurediz@gmail.com

Prof. Michael J. Ostwald

The University of Newcastle

School of Architecture

Callaghan

NSW, 2308

Australia

Michael.Ostwald@newcastle.edu.au 